\title{
PERBANDINGAN EFISIENSI SEL FOTOVOLTAIK BERBASIS DSSC DARI EKSTRAK ZAT WARNA SEGAR DAN KERING TUMBUHAN SECANG, TARUM DAN PACAR KUKU
}

\author{
Iswadi Ibrahim Patunrengi ${ }^{1}$, Aisyah ${ }^{2}$ \\ ${ }^{1}$ Jurusan Fisika UIN Alauddin Makassar \\ ${ }^{2}$ Jurusan Kimia UIN Alauddin Makassar \\ E-mail: wadi.phys.dept@uin-alauddin.ac.id
}

\begin{abstract}
Solar energy is the most abundance energy source in the world. However, it is used only limited amount for energy conversion. Photovoltaics system is one method to harvest energy from the sun and convert it to electricity. In this research, the fresh and dried extract of organic dyes from Secang wood; Tarum leaves (Indigofera tinctoria) and Pacar Kuku leaves (Lawsonia inermis L) are used as a sensitizer in solar cells. Results shows that efficiency of photovoltaic cells from fresh extract are higher than the dried one. The efficiency of fresh dyes from Secang, Tarum and Pacar Kuku are 1,26\%; 0,74\% and 0,21\% respectively. Meanwhile, efficiency of dried extracts are 1,26\%; 0,74\% and 0,21\% respectively.
\end{abstract}

Keywords: Energy conversion, Photovoltaics, efficiency, fresh and dried extract.

\section{PENDAHULUAN}

$\mathrm{E}$ nergi adalah salah satu isu yang selalu hangat dalam setiap diskusi ilmiah bahkan mungkin hingga akhir zaman. Hal ini disebabkan karena kebutuhan akan energi semakin bertambah seiring dengan bertambahnya jumlah penduduk dunia sedangkan sumber energi yang tersedia di bumi semakin hari semakin berkurang.

Sebagai negara tropis yang membentang dari timur ke barat tepat dibawah equator, seharusnya Indonesia tidak perlu khawatir kekurangan sumber energi sebab terdapat energi matahari yang sangat melimpah. Energi dari matahari ini dapat di konversi menjadi energi listrik yang disebut energi surya dengan teknologi sel surya (Photovoltaics). Salah satu jenis sel surya yang sedang dikembangkan adalah sel surya berbasis warna (dyes) dari tumbuhan yang lebih dikenal dengan Dye Sensitized Solar Cell (DSSC). Sel surya yang berbasis fotoelektrokimia yang pertama kali ditemukan oleh Michael Gratzel (1991) yang telah menjadi topik penelitian intensif oleh peneliti diseluruh dunia. DSSC disebut juga terobosan pertama dalam teknologi sel surya sejak sel surya silikon.

Sebuah DSSC terdiri dari elektroda semikonduktor bernanokristalin penyerap warna, elektroda counter, dan elekroda yang mengandung ion iodida dan tri-iodida. Sensitizer mempunyai peranan penting dalam menyerap sinar matahari dan mengubah energi matahari menjadi energi listrik. Efisiensi tertinggi DSSC terdapat pada Ru 
Complex N719 yang mencapai 11-12 \% (Zhou, dkk, 2011). Namun dye dari Ruthenium Complex ini termasuk zat pewarna sintesis yang cukup mahal. Sedangkan dye alami dapat di ekstrak dari bagian-bagian tumbuhan seperti daun, bunga dan buah (Dewi, dkk, 2010). Indonesia yang kaya akan biodiversity memiliki berbagai jenis tumbuhan yang dapat menghasilkan zat warna yang dapat mengkonversi energi cahaya menjadi energi listrik. Zat warna berfungsi sebagai penyerap radiasi matahari dan semikonduktor celah lebar seperti $\mathrm{TiO}_{2}$ sebagai transport pembawa muatan. Pigmen dengan karakter serapan elektronik yang lebar di daerah cahaya tampak dari spektrum cahaya matahari secara teoritis akan menyerap radiasi matahari dalam jumlah lebih banyak dan merupakan sensitizer yang baik (Kartini, dkk, 2008).

Penelitian DSSC telah banyak dilakukan pada berbagai macam dye sensitizer (zat pewarna alami) dari berbagai ekstrak bahan organik baik antosianin, cyanin, xantofil, tanin, maupun klorofil. Penggunaan Antosianin sebagai dye lebih dulu dan telah banyak dikembangkan seperti Kol Merah (Maddu, dkk, 2007), Buah Buni (Pangestuti, 2009), Kulit Manggis (Zhou, dkk, 2010), Kulit Terong Ungu (Astuti, 2012 dan Risnah, dkk.,2018), Ubi Jalar Ungu (Sasmiyanto, 2013), Jahe Merah (Ekasari, 2013), buah Strawberry (Misbachudin, 2013). Selain Antosianin dilakukan juga penelitian terhadap klorofil pada beberapa Jenis daun Tumbuhan Seperti Daun Suji (Darmawan, dkk, 2014), Daun Bayam (Kumara, dkk, 2012), Daun Cincau (Prananto, dkk, 2013), Daun Jarak pagar, Daun Jati (Baharuddin, dkk. 2015), daun Pepaya (Pramono, dkk, 2014) dan Daun Putri Malu (Patunrengi, dkk. 2019), namun nilai efesiensi yang dihasilkan dari bahan-bahan tersebut masih terhitung rendah. Efesinsi yang tertinggi dari berbagai penelitian adalah kulit manggis yaitu 1,17 \% (Zhou, dkk, 2010). Tanaman sirsak (Annona muricata L). Buahnya mengandung banyak serat, karbohidrat, vitamin dan mineral, sedangkan daunnya mengandung senyawa asetogenin, tanin, fitosterol, kalsium oksalat, alkaloid murisin, flavonoida dan steroida (Suranto, 2011). Pada daun sirsak terdapat dua pigmen yang dapat dijadikan pewarna alami yaitu klorofil yang menghasilkan warna hijau dan senyawa tanin yang memberikan warna kuning kejinggaan. Warna hijau dapat menyerap warna cahaya ungu (400-435 nm) sedangkan warna kuning kejinggaan dapat menyerap warna cahaya biru (435-490 nm) (Kumara, dkk, 2012:5). Peneliti telah mendapatkan efisiensi konversi energi yang lebih baik pada turunan dyes klorofil tersebut karena memiliki gugus carboxylate (Wang Song, dkk, 2007: 4).Penelitian yang sama juga telah kami lakukan dengan bahan dari ekstrak daun, buah dan bunga sirsak dan putri malu dengan hasil yang sangat baik (Ardian, dkk, 2016).

Telah banyak penelitian yang telah dilakukan namun tidak semua hasil yang diperoleh memungkinkan penerapannya ketahap yang lebih lanjut seperti fabrikasi panel. Hal ini karena nilai efisiensi yang diperoleh masih sangat kecil sehingga menjadi tidak efektif. Selain itu sifat kestabilan sel yang dibuat juga kurang baik sehingga tidak dapat bertahan lama. Terdapat beberapa hal yang diyakini sebagai penyebab kedua hal tersebut, yakni proses ekstraksi zat warna (basah dan kering) yang kurang baik, penggunaan $\mathrm{TiO} 2$ yang kasar, proses pemanasan saat karakterisasi, pelarut elektrolit dan penggunaan kaca panel sel surya yang berbeda. Penelitian ini akan berfokus pada efisiensi sel fotovoltaik dengan menggunakan ekstrak basah dan kering dari tumbuhan endemik tropis sebagai bahan sensitizer baik ekstrak tunggal maupun campuran dari beberapa zat warna. 


\section{Rumusan Masalah}

Rumusan masalah dalam penelitian ini adalah Bagaimana nilai effisiensi sel fotovoltaik berbasis DSSC dari ekstrak secang, tarum dan pacar kuku masing-masing untuk sampel basah dan sampel kering.

\section{Tujuan Penelitian}

Tujuan penelitian ini adalah untuk mengetahui efisiensi dan kestabilan energi listrik sel fotovoltaik yang dihasilkan dari ekstrak warna (daun, buah dan bunga) tumbuhan endemik tropis.

\section{Dye sensitized Solar cells (DSSC)}

Beda potensial yang dihasilkan oleh sel surya DSSC berasal dari perbedaan tingkat energi konduksi elektroda semikonduktor $\mathrm{TiO}_{2}$ dengan potensial elektrokimia pasangan elektrolit redoks $\left(\mathrm{I}^{-} / \mathrm{I}^{3-}\right)$. Sedangkan arus yang dihasilkan dari sel surya ini terkait langsung dengan jumlah foton yang terlibat dalam proses konversi dan bergantung pada intensitas penyinaran serta kinerja dye yang digunakan ( $\mathrm{Li} \mathrm{B}$, dkk, 2006).

Penentuan efisiensi DSSC dilakukan dengan metode kurva arus dan tegangan. Tujuannya adalah untuk mengetahui keefektifan dari suatu susunan komponen DSSC dalam mengubah energi matahari mernjadi energi listrik yang dinyatakan dalam persen.Pengujian sel surya dilakukan untuk menentukan besaran-besaran yang dibutuhkan dalam pengukuran efisiensi DSSC. Besaran tersebut adalah tegangan rangkaian terbuka $\left(\mathrm{V}_{\mathrm{oc}}\right)$, arus hubungan pendek $\left(\mathrm{I}_{\mathrm{sc}}\right)$, tegangan optimum $\left(\mathrm{V}_{\mathrm{mpp}}\right)$, arus optimum dan fill factor (FF) (Dewi, dkk, 2010).

Kurva arus dan tegangan (I-V) dapat dilihat pada gambar berikut.

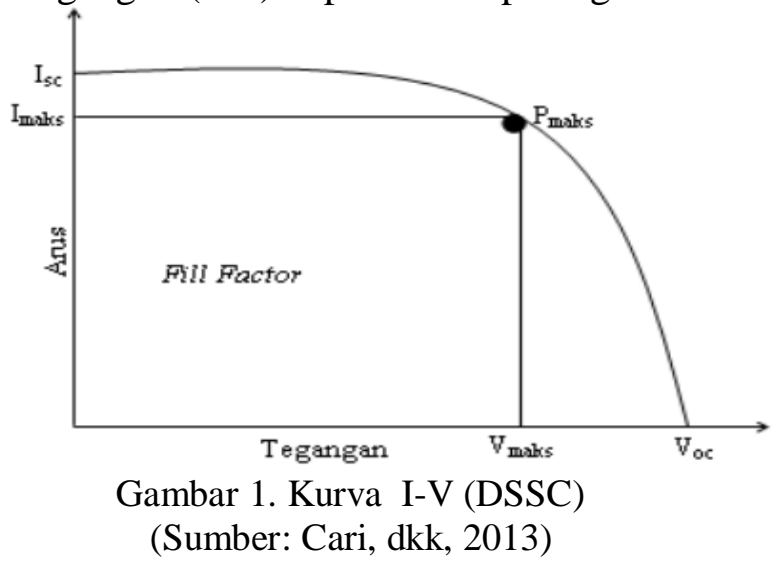

Kurva diatas menujukan kemapuan sel dalam memproduksi tegangan dan arus.Pada Gambar 1 tersebut diperlihatkan tegangan open circuit $\left(\mathrm{V}_{\mathrm{oc}}\right)$, arus short circuit $\left(\mathrm{I}_{\mathrm{is}}\right)$, tegangan maksimum, arus maksimum dan fill factor. Saat kondisi short circuit $\left(\mathrm{I}_{\mathrm{is}}\right)$, sel akan menghasilkan arus maksimun atau arus short circuit. Saat kondisi open circuit tidak ada arus yang mengalir sehingga tegangannya akan menjadi maksimum atau disebut dengan tegangan open circuit. Fill factor (FF) merupakan suatu ukuran kuantitatif kualitas performa suatu sel surya, serta merupakan ukuran luar persegi kurva I-V, Fill Factor dapat diperoleh menggunakan persamaan 1 :

$$
F F=\frac{V_{\text {maks } I_{\text {maks }}}}{V_{o c} I_{s c}}
$$


Daya maksimum yang dihasilkan sel surya dapat diperoleh melalui persamaan 2

$$
P_{m a k s}=V_{o c} I_{s c} F F
$$

Untuk mengetahui nilai daya sesaat atau efesiensi yang dihasilkan oleh sel surya, terlebih dahulu menghitung daya yang diterima (daya input), dimana daya tersebut adalah perkalian antara intensitas radiasi matahari yang diterima dengan luas area PV module dengan persamaan:

$$
P_{\text {in }}=E \times A
$$

Efisiensi $(\eta)$ yang dihasilkan sel surya dapat diperoleh melalui persamaan 3.

$$
\eta=\frac{P_{\text {maks }}}{P_{\text {in }}} \times 100 \%
$$

Dimana :

$$
\begin{aligned}
& \eta=\text { Efisiensi }(\%) \\
& \mathrm{P}_{\text {maks }}=\text { daya maksimum DSSC }\left(\mathrm{mW} / \mathrm{cm}^{2}\right) \\
& \mathrm{P}_{\mathrm{in}}=\text { Daya Sinar Matahari }\left(\mathrm{mW} / \mathrm{cm}^{2}\right)
\end{aligned}
$$

Efisiensi menjadi ukuran global kualitas dari sel surya. Efisiensi sel surya yang merupakan perbandingan kuantitatif dari daya maksimum yang dihasilkan sel $\left(\mathrm{P}_{\max }\right)$ dengan daya dari cahaya yang datang ( $\left.\mathrm{P}_{\text {cahaya }}\right)$ (Darmawan, dkk, 2014). Nilai $\mathrm{P}_{\text {in }}$ didapatkan daya sinar matahari yang menyinari Indonesia bagian barat yaitu senilai 450 $\mathrm{mW} / \mathrm{cm}^{2}$ (Prasatya, dkk, 2012).

\section{METODE PENELITIAN}

Penelitian ini dilakukan di tiga laboratorium berbeda yakni proses ekstraksi zat warna akan dilakukan di laboratorium kimia organik, proses fabrikasi, karakterisasi dan uji efisiensi dan kestabilan dilakukan di laboratorium fisika modern UIN Alauddin Makassar. Sedangkan uji UV-VIS, SEM, XRD dan XRF sampel akan dilakukan di Laboratorium Mokrostruktur jurusan fisika Universitas Negeri Makassar, Universitas Hasanuddin dan ITS.

Proses pengujian sel surya yang telah di fabrikasi dilakukan dibawah sinar matahari langsung (under sun illuminated). Proses ini dibutuhkan untuk menguji besar arus dan tegangan yang dihasilkan oleh sel surya. Untuk memudahkan proses penentuan nilai maksimum dan nilai minimum arus dan tegangan, maka di gunakan potensiometer 10-20 kiloOhm. Hasil yang diperoleh akan memberikan gambaran efktivitas dari sel yang telah di buat, dimana nilai tersebut akan menjadi nilai output dari sel surya. Adapun nilai input diperoleh dari intensitas matahari yang diukur saat itu. Intensitas ini di ukur menggunakan Luxmeter dan hasilnya di konversi kedalam watt perluasan tertentu $(\mathrm{cm})$. 


\section{HASIL DAN PEMBAHASAN}

\section{a. Hasil Uji UV-VIS}

\section{Uji UV-VIS sampel segar 24 jam}

Selain sampel segar dengan waktu maserasi 24 jam juga dilakukan sampel pada waktu perendaman lebih dari 24 jam dan sampel kurang dari 24 jam. Namun tidak semua sampel yang ada (pada samapel 24 jam) di lakukan uji UV-VIS. Jumlah sampel yang di uji sebanyak 5 sampel sebagaimana diperlihatkan pada gambar 3 berikut;

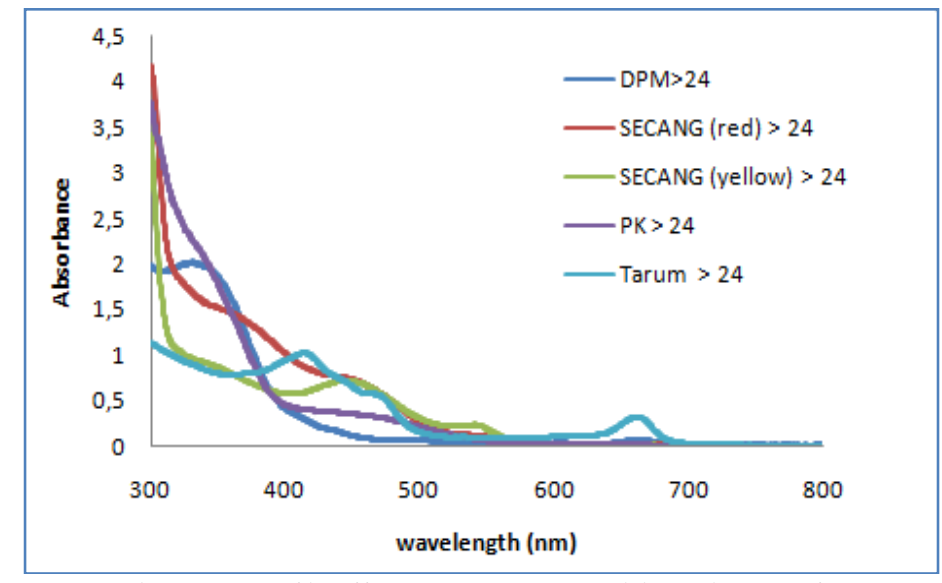

Gambar 3. Hasil Uji UV-VIS sampel basah > 24 jam

Nilai absorbansi yang diperoleh lebih rendah dari absorbansi pada sampel 24 jam namun memiliki puncak yang beragam yang tersebar pada rentang panjang gelombang $350 \mathrm{~nm}$ hingga $700 \mathrm{~nm}$. Jumlah puncak terbanya diberikan oleh daun Tarum 4 puncak dengan puncak tertinggi (absorbansi) sekitar 1,2 pada panjang gelombang $420 \mathrm{~nm}$. Jumlah puncak (peak) absorbsi sangat mempengaruhi nilai energi yang dapat diserap oleh ekstrak dye.

\section{Uji UV-VIS sampel kering 24 jam}

Untuk sampel kering terdapat tiga buah ekstrak sampel yang di uji yani, Secang (Merah), Pacar Kuku dan Tarum. Hasil uji menunjukkan bahwa daun Tarum dan Pacar kuku memiliki nilai absorbansi lebih dari 10 pada range panjang gelombang $300 \mathrm{~nm}$ hingga $450 \mathrm{~nm}$ sehingga nilai tersebut perlu diketahui dengan menguji kembali namun dengan pengenceran ekstrak hingga 1000 kali lebih rendah. Namun demikian kedua sampel tersebut memiliki beberapa puncak lain yang juga sangat tinggi, yakni pada panjang gelombang sekitar $680 \mathrm{~nm}$. Sedangkan secang kering memiliki nilai absrbansi yang lebih kecil dengan jumlah peak yang juga lebih sedikit. 


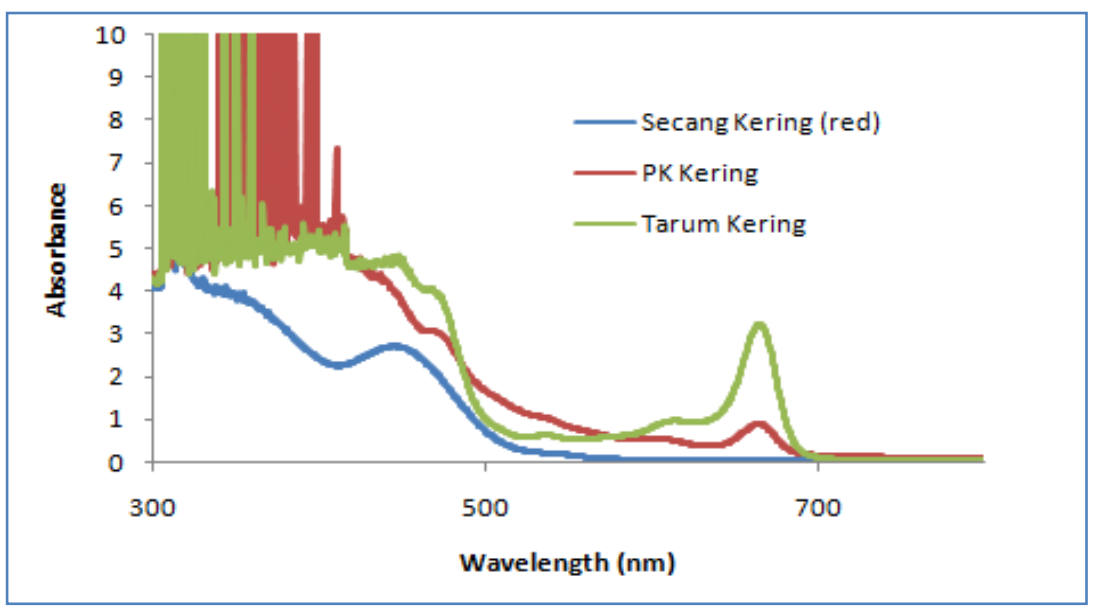

Gambar 4 Hasil Uji UV-VIS sampel kering 24 jam

\section{b. Hasil FTIR}

Ekstrak dye tiap sampel selain di uji UV-VIS juga perlu dilakukan uji FTIR. Uji FTIR perlu dilakukan untuk melihat nilai transmitansi dari tiap zat warna. Nilai transmitansi ini memberikan gambaran besarnya energi yang diterima olehtiap dye. Jumlah sampel yang di uji sebanyak 5 sampel yakni, Daun putri malu, bunga putri malu Secang (red) dan Tarum, sedangkan sampel lain tidak semuanya di uji. Hasil uji FTIR tiap sampel dapat dilihat pada gambar berikut;

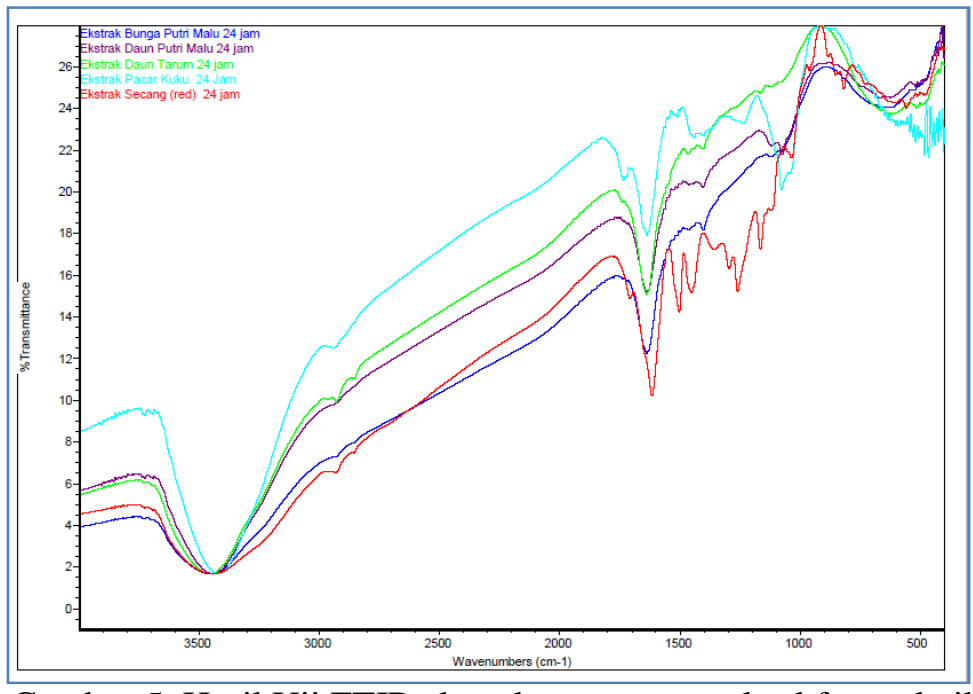

Gambar 5. Hasil Uji FTIR ekstrak warna sampel sel fotovoltaik

Hasil uji FTIR sebagaimana yang ditunjukkan pada gambar 4.13 menunjukkan bahwa secara umum semua sampel memiliki nilai transmitansi dengan karakter yang mirip satu sama lain. Hal ini menunjukkkan bahwa kemampuan transmisi energi yang diterima tiap sampel juga tidak jauh berbeda, sehingga berimplikasi pada kemampuan absorbsi energi dari tiap sampel uji. 


\section{c. Pengujian Sel Fotovoltaik}

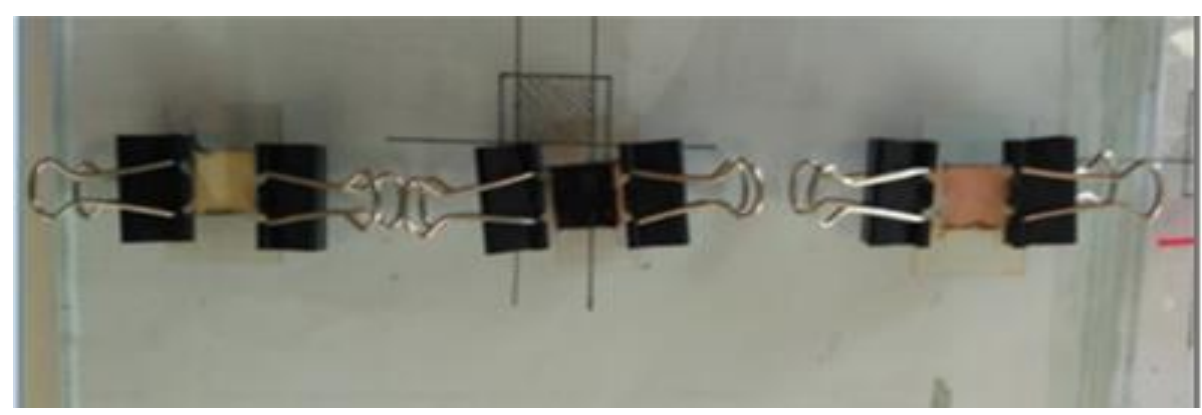

Gambar 6. Sel fotovoltaik yang telah jadi (tanpa elektrolit)

Proses pengujian sel surya yang telah di fabrikasi dilakukan dibawah sinar matahari langsung (under sun illuminated). Proses ini dibutuhkan untuk menguji besar arus dan tegangan yang dihasilkan oleh sel surya. Untuk memudahkan proses penentuan nilai maksimum dan nilai minimum arus dan tegangan, maka di gunakan potensiometer 10-20 kiloOhm. Hasil yang diperoleh akan memberikan gambaran efektivitas dari sel yang telah di buat, dimana nilai tersebut akan menjadi nilai output dari sel surya. Adapun nilai input diperoleh dari intensitas matahari yang diukur saat itu. Intensitas ini di ukur menggunakan Luxmeter dan hasilnya di konversi kedalam watt perluasan tertentu (cm). Hasil pengukuran disajikan pada gambar berikut;

\section{Uji Tegangan dan kuat arus (kurva I-V)}

Sel surya yang telah difabrikasi diuji dibawah matahari langsung dan memberikan hasil yang berbeda untuk tiap jenis bahan dye yang digunakan sebagaimana yang diperlihatkan pada gambar berikut;

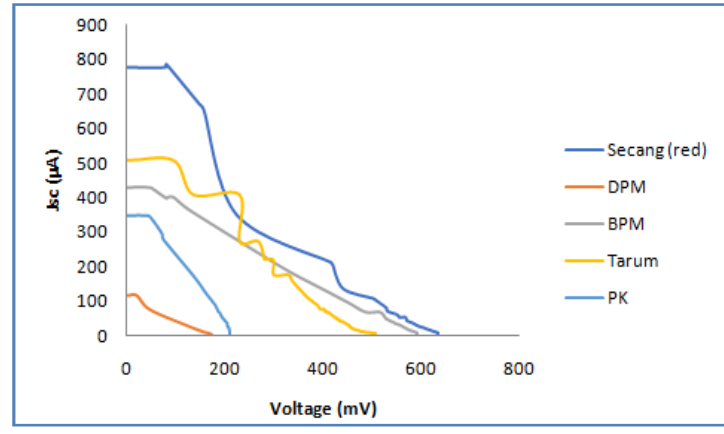

(a)

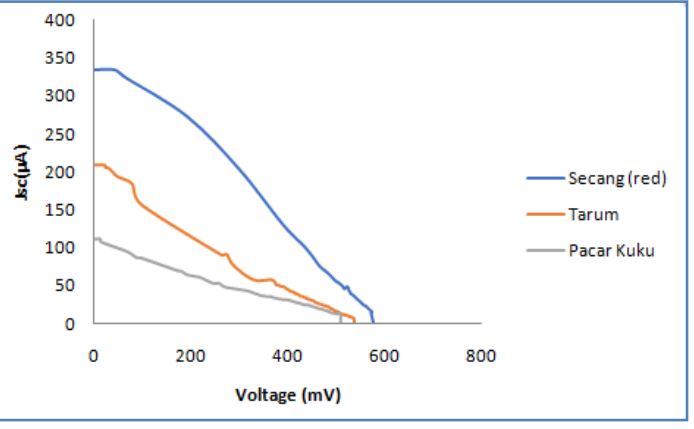

(b)

Gambar 7 Kurva I-V, (a) Sampel Segar, (b) sampel Kering

Gambar 7a memperlihatkan sebaran arus dan tegangan yang diperoleh dari lima jenis sel surya. Nilai arus dan tegangan yang paling tinggi diberikan oleh sel surya dengan ekstrak warna Secang merah. Nilai tegangan mencapai nilai maksimal $634 \mathrm{mV}$ dan nilai arus maksimum sebesar $778 \mu \mathrm{A}$. Sedangkan sel surya dengan nilai terendah diberikan oleh sel surya ekstrak daun putri malu (DPM) dengan nilai arus dan tegangan maksimum masing-masing sebesar $117 \mu \mathrm{A}$ dan $175 \mathrm{mV}$. Tiga sel surya lainnya (tarum, bunga putri malu dan pacar kuku) memiliki arus pada rentang $350 \mu \mathrm{A}-530 \mu \mathrm{A}$ dan tegangan pada rentang $220 \mathrm{mV}-610 \mathrm{mV}$. Sedangkan pada gambar $7 \mathrm{~b}$, nilai arus dan tegangan diberikan masing-masing dengan nilai maksimum $335 \mu \mathrm{A}$ dan $577 \mathrm{mV}$. Nilai 
tersebut masih berada dibawah nilai arus dan dan tegangan untuk sel surya ekstrak segar namun tetap berada pada posisi pertama untuk sel surya ekstrak sampel kering. Sel surya berbahan ekstrak tarum menempati posisi kedua dengan nilai arus dan tegangan maksimum masing-masing sebesar $209 \mu \mathrm{A}$ dan $536 \mathrm{mV}$ secara berturut-turut. Nilai arus dan tegangan untuk dye kering terendah diberikan oleh sel surya pacar kuku dengan nilai arus dan tegangan terendah sebesar $112 \mu \mathrm{A}$ dan $508 \mathrm{mV}$ secara berurutan.

\section{Penentuan efisiensi sel surya}

Nilai efisiensi dari setiap sel surya dapat ditentukan berdasarkan kurva Arus dan tegangan yang telah dibuat sebelumnya. Besarnya nilai tersebut ditentukan dengan terlebih dahulu menentukan nilai fill factor untuk setiap sel. Hasil perhitungan berdasarkan persamaan 4 memberikan nilai efisiensi untuk masing-masing sel surya disajikan pada tabel berikut;

Tabel 1 Efisiensi sel surya sampel kering

\begin{tabular}{lcccccc}
\hline \multicolumn{1}{c}{ Sampel } & Voc (V) & Isc (A) & P in & FF & P out & $\eta(\%)$ \\
\hline Secang (red) & 0,577 & 0,335 & 7,11567 & 0,31506 & 0,06090 & 0,86 \\
\hline Tarum & 0,536 & 0,209 & 13,92387 & 0,22014 & 0,02466 & 0,18 \\
\hline Pacar Kuku & 0,508 & 0,112 & 7,40849 & 0,23940 & 0,01362 & 0,18 \\
\hline
\end{tabular}

Hasil diatas menunjukkan bahwa untuk sampel kering, sel surya dengan nilai efisiensi tertinggi diberikan oleh Secang (red) dengan efisiensi sebesar 0, 86 persen sedangkan dua sel surya lainnya memberikan nilai efisiensi yang sama yakni 0,18 persen. Nilaiefisiensi untuk sel surya dengan sampel segar ditunjukkan pada tabel berikut;

Tabel 2 Efisiensi sel surya sampel segar

\begin{tabular}{lcccccc}
\hline \multicolumn{1}{c}{ Sampel } & Voc (V) & Isc (A) & P in & FF & P out & $\eta(\%)$ \\
\hline Secang (red) & 0,634 & 0,778 & 8,12592 & 0,20747 & 0,1023 & 1,26 \\
\hline Tarum & 0,508 & 0,509 & 12,70864 & 0,36381 & 0,0941 & 0,74 \\
\hline Pacar Kuku & 0,461 & 0,212 & 12,41581 & 0,59558 & 0,0259 & 0,21 \\
\hline
\end{tabular}

Pada sampel segar nilai efisiensi sel surya tertinggi diberikan oleh sampel dye secang dengan efisiensi sebesar 1,2 persen. Sedangkan nilai terendah diberikan oleh sel surya dengan dye daun putrimalu (DPM). Tiga sel lainnya memberikan nilai efisiensi antara 0,15 persen hinggga 0,75 persen. Nampak bahwa nilai untuk sampel segar jauh lebih tinggi dibandingkan dengan efisiensi sel surya sampel kering.

\section{KESIMPULAN}

Berdasarkan hasil penelitian yang telah dilakukan maka dapat disimpulkan bahwa nilai efisiensi ekstrak sampel basah lebih baik dari pada ekstrak kering. Untuk ketiga sel fotovoltaik 0,$86 ; 0,18 ; 0,18$ masing-masing untuk ektrak kering dari secang, tarum dan pacar kuku secara berurutan. Sedangkan untuk sampel segar 1,26; 0,74 dan 0,21 masing-masing dengan urutan yang sama. 


\section{DAFTAR PUSTAKA}

Baharuddin, Aminuddin, Aisyah, A., Jawiana, S., dan Indah, AR. 2015, Karakterisasi Zat Warna Daun Jati (Tectona grandis Fraksi Metanol:n-Heksan Sebagai Fotosensitizer Pada Dye Sensitized Solar Cell, Chimica et Natura, 3(1):

$37-41$.

Chen, Xianfeng, Chen Jingfei, Jia Lin. 2011. High-efficiency dye-sensitized solar cells basedon robust and both-end-open TiO2 nanotube membranes. Journal of Nanoscale Research Letters China : Department of Physics, Shanghai Jiao Tong University.

Gratzel, Michael. 2003. Dye-Sensitised Solar Cells, journal of Photochemistry and Photobiology. Vol.4, 145-153. Switzerland : Swiss Federal Institute of Technology.

Gratzel, M dan O'regan. 1991.A Low-Cost, High Efficiency Solar Cell Based On Dye-Sensitized Colloidal $\mathrm{TiO}_{2}$ Films. Jurnal of Nature Vol. 353, Issue 63466, 737.Switzerlad : Swiss Federal institute of Technology.

Hardeli, Suwardani, Riky, Fernando T, Maulidis, Silvia Ridwan .2013. Dye Sensitized Solar Cells (DSSC) BerbasisNanopori TiO2 Menggunakan Antosianin dari Berbagai Sumber Alami. Jurnal. Padang : FMIPA UNP.

International Energy Agency.2011."Renewables for Heating and Cooling".(Diakses 15 Februai 2017).

Kumara, Maya Sukma Widya, Drs. Gontjang Prajitno, M.Si. 2012. Studi awal Fabrikasi Dye Sensitized Solar Cell (DSSC) dengan Menggunakan Ekstraksi Daun Bayam (Amaranthushybridus L.) Sebagai Dye Sensitizer dengan Variasi Jarak Sumber Cahaya pada DSSC. Jurusan Fisika, FMIPA, Institut Teknologi Sepuluh Nopember :Surabaya

Li B, Wang L, Kang B, Wang P \& Qiu Y, 2006, "Review of Recent Progress in Solid-State DyeSensitized Solar Cells. Sol. Energy Mater. Sol. Cells”, 90:549-573

Maddu A, ,Zuhri M dan Irmansyah. 2007.Penggunaan Ekstrak Antosianin Kol Merah sebagai Fotosensitizer pada Sel Surya TiO2 Nanokristal Tersensitisasi Dye. Makara Teknologi Vol. 11, No. Bogor : Departemen Fisika FMIPA, Institut Pertanian Bogor.

Misbachudin, M.C., S. Trihandaru, A. Sutresno. 2013. Studi Awal Ekstrak Antosianin Strawberry sebagai Fotosensitizer dalam Pem-buatan Prototipe Dye Sensitized Solar Cell (DSSC). Jurnal LPF 1350. Salatiga : Universitas Kristen Satya Wacana

Nadeak, Sahat Marthua Reynard. Diah Susanti. 2012. Variasi Temperatur dan Waktu Tahan Kalsinasi terhadap Unjuk Kerja Semikonduktor TiO2 sebagai Dye Sensitized Solar Cell (DSSC) dengan Dye dari Ekstrak Buah Naga Merah. Institut Teknologi Sepuluh Nopember (ITS).

Nygren, Kristian. 2010. Solar cells based on synthesized nanocrystalline ZnO thin films sensitized by chlorophyll $a$ and photopigments isolated from spinach. Swedish : Department of Physics, Chemistry and Biology, Linköping University.

Pangestuti, D.L. 2009. Pembuatan Dye-Sensitized Solar Cell dengan Sensitizer Antosianin dari Buah Buni. Semarang : Jurusan Kimia, Universitas Diponegoro.

Patunrengi, I.I., Aisyah, A., Sahara, S., Fuadi, N., Ardian, A., Muarif, M, 2019. A new study of dyesensitized solar cell from the extract of leaf, fruit, and mix of Mimosa pudica Linn, $2^{\text {nd }}$ International Conference on Science and Technology.

Risnah, Indah A.,Aisyah A., Iswadi, I dan Jawiana S., 2018, The Photosenzitiser from The Basic Dye Extract of The Skin of Eggplant (Solanum melongena L.), Al-Kimia, 6(1): 1-9.

Sastrawan, R. 2006 Photovoltaic Modules of Dye Solar Cells, Disertasi University of Freiburg.

Smestad Gerg. P dan Gratzel, M. 1998. Demonstrating Electron Transfer and Nanotechnology : A Natural Dye - Sensitized Nanocrystalline Energy Converter. Journal of Chemical Education.Vol 75 No. 6.Switzerland : Swiss Federal Institute of Technology. 
Wang Song, Wu Xiaohong, Qin Wei, Jiang Zhaohua. 2007. TiO2 films prepared by micro-plasma oxidation method for dye-sensitized solar cell. Eletrochimia Acta 53.China : Institute of Plasma physics, Chinese Academy of Sciences.

Zhou, Huizhi, Liqiong Wu, Yurong Gao, Tingli Ma.2011. Dye-sensitized solar cells using 20 natural dyes as sensitizers. Journal of Photochemistry and Photobiology A. China : Dalian University of Technology. 